\title{
Pengaruh Pemberian Kapur Pada Air Gambut Terhadap Kelangsungan Hidup Dan Pertumbuhan Benih Ikan Gabus (Channa striata)
}

\section{The Effect of lime in Peat Water on the Survival Rate and Growth of Snack Head (Channa striata) Seeds.}

\author{
Shinta S. Monalisa, *Maryani, Kamisa Rumapea \\ Program Studi Budidaya Perairan Jurusan Perikanan Fakultas Pertanian Universitas Palangka Raya \\ Jl. Yos Sudarso, Palangka, Kec. Jekan Raya, Kota Palangka Raya, Kalimantan Tengah 74874 \\ *e-korespondensi : maryani@ fish.upr.ac.id
}

\begin{abstract}
This research was conducted to determine the effect of giving different lime on the survival rate and growth of snack head seeds. This writing uses a completely randomized design (CRD) with 4 treatments and 3 replications. The hypothesis being tested was that the application of the limed lime had no significant effect on survival rate, the growth of snack head seed and the specific growth rate and lime administration differed significantly in feed conversion. The study was conducted at the Wet Aquaculture Laboratory, Palangka Raya University starting from February 3 - March 3, 2020. The results showed that the administration of different lime had no significant effect on survival rate, growth and specific growth rates but had a significant effect on feed conversion. The best survival rate of snack head seeds is in treatment D $(250 \mathrm{~g})$ that is equal to $57.73 \%$, the best weight growth is in treatment $C(200 \mathrm{G})$ that is equal to 3.16 grams, the best length growth is in treatment D (250 g) that is 2.57 $\mathrm{cm}$, the best specific growth rate is in treatment $D(250 \mathrm{~g})$ which is $2.92 \%$ / day, and the best feed conversion value is in treatment $D(250 \mathrm{~g})$ which is $1.47 \%$. Water quality such as temperature, acidity $(\mathrm{pH})$ and dissolved oxygen (DO) are still in the normal range.
\end{abstract}

Keywords : cork fish, lime, survival rate and growth, peat.

\section{PENDAHULUAN}

Air gambut adalah air permukaan yang banyak dijumpai di daerah lahan gambut atau dataran rendah terutama di pulau Kalimantan dan Sumatera. Menurut Ashari (2012) air gambut adalah air permukaan yang banyak terdapat di daerah rawa maupun dataran rendah yang mempunyai ciri-ciri yaitu berwarna coklat tua sampai kehitaman (124 - 850 PtCo), berkadar organik tinggi (138 - $1560 \mathrm{mg} / \mathrm{lt} \mathrm{KMnO4),} \mathrm{dan} \mathrm{bersifat} \mathrm{asam} \mathrm{(pH} \mathrm{3,7} \mathrm{-} \mathrm{5,3).}$ Faktor rendahnya $\mathrm{pH}$ perairan ini merupakan kendala utama bagi pengembangan budidaya ikan, sehingga untuk mengoptimalkan potensi lahan gambut dalam bidang perikanan diperlukan suatu teknologi untuk menanggulangi masalah $\mathrm{pH}$ rendah yang ada.Salah satunya yaitu melalui pendekatan biologis dengan pemanfaatan ikan lokal yang telah beradaptasi dengan lingkungan tersebut(Gleni dan Rudhy, 2013). Secara umum perkembangan budidaya ikan air tawar di Provinsi Kalimantan Tengah masih didominasi oleh budidaya kolam menggunakan air dari pasang surut sungai.Dengan demikian seringkali terkendala karena datangnya air asam dengan $\mathrm{pH}$ sangat rendah $( \pm 3)$ sampai menyebabkan kematian secara total.Dapat dikemukakan bahwa faktor rendahnya $\mathrm{pH}$ merupakan kendala utama bagi pengembangan budidaya ikan di Provinsi Kalimantan Tengah (Gleni Hasan Huwoyon, 2010). Pada umumnya ikan ikan lokal perairan gambut didominasi oleh jenis-jenis ikan yang mampu mengambil/bernapas menggunakan oksigen dari udara (air breathing), seperti ikan betok/papuyu (Anabas testudineus) dan gabus/haruan (Channa striata). Ikan gabus merupakan salah satu jenis ikan yang habitatnya ditemukan diperairan sungai dan rawa banjiran. Budidaya ikan gabus belum banyak mendapat perhatian disebabkan masih minimnya informasi teknologi budidaya.

Ikan gabus termasuk jenis ikan air gambut yang belum berhasil dibudidayakan secara intensif. Hal tersebut disebabkan mortalitas yang tinggi selama pemeliharaan benih dan kualitas benihyang tidak sesuai. Berdasarkan hal tersebut maka perlu dilakukan suatu upaya untuk budidaya ikan gabus sehingga ketersediannya continue.Berdasarkan hal tersebut, maka dilakukan penelitian ini untuk melihat pengaruh pemberian kapur terhadap kelangsungan hidup dan pertumbuhan benih ikan gabus (Channa striata) menggunakan air gambut. 


\section{Waktu dan Tempat}

\section{METODE PENELITIAN}

Penelitian ini dilaksanakan pada bulan Febuari - Maret 2020, di Laboratorium Basah Program Studi Budidaya Perairan Jurusan Perikanan, Fakultas Pertanian, Universitas Palangka Raya.

\section{Alat dan Bahan}

Alat-alat yang digunakan dalam penelitian ini adalah : 1) ember 12 buah, 2) $\mathrm{pH}$ meter, 3) DO meter, 4) Thermometer, 5) Papan ukur, 6) Timbangan digital, 7) Serokan.

Bahan-bahan yang digunakan dalam penelitian ini adalah : 1) Benih ikan gabus, 2) Air gambut, 3) Pakan Buatan, 4) Kapur.

\section{Rancangan Percobaan}

Rancangan percobaan yang digunakan pada penelitian ini yaitu metode RAL(RancanganAcakLengkap). Penelitian ini terdiri dari empat perlakuan yaitu kontrol $(\mathrm{K})$ dan perlakuan dengan penambahan kapur dengan dosis $150 \mathrm{~g}, 200 \mathrm{~g}, 250 \mathrm{~g}$ dan setiap perlakuan terdiri dari tiga ulangan.

Perlakuan $\mathrm{A} \quad=$ Tanpa kapur (kontrol)

Perlakuan $\mathrm{B} \quad=$ Penambahan kapu $150 \mathrm{gr}$

Perlakuan C = Penambahan kapur $200 \mathrm{gr}$

Perlakuan D = Penambahan kapur 250 gr

Hipotesis

$\mathrm{H}_{0}=$ Pemberian dosis kapur yang berbeda tidak berpengaruh terhadap pertumbuhan benih ikan gabus.

$\mathrm{H}_{1}=$ Penggunaan dosis kapur yang berbeda berpengaruh terhadap pertumbuhan benih ikan gabus.

\section{Prosedur Penelitian}

\section{Persiapan Wadah Pemeliharaan dan Aklimatisasi Ikan}

Wadah yang digunakan yaitu ember sebanyak 12 buah. Wadah pemeliharaan dicuci dengan sabun deterjen dan dibersikan dengan air bersih dan dikeringkan selama 1 hari. Air yang digunakan sebagai media hidup ikan sebelumnya harus diendapkan terlebih dahulu dalam wadah penampungan air dan air yang digunakan yaitu air galian parit MIPA UPR. Setelah itu benih ikan gabus ditebar kedalam wadah penampungan air gambut, dan dilakukan aklimatisasi selama 3 hari. Selama proses aklimatisasi ikan diberi pakan secara at satiation (diberi makan sampai kenyang). Frekuensi pemberian pakan selama masa aklimatisasi sebanyak dua kali sehari pada pagi hari pukul 08.00 WIB dan sore hari pukul 17.00 WIB.

\section{Penambahan kapur}

Sebelum air kapur dimasukkan kedalam ember, kapur terlebih dahulu ditimbang sesuai metode penelitian dengan perlakuan (A) tanpa kapur (control), perlakukan (B) 150 gram, Perlakuan (C) 200 gram dan perlakuan (D) 250 gram, kemudian kapur dilarukan pada air yang sudah disediakan. Setelah air kapur terlarut, kapur didiamkan selama 1 hari.Setelah air kapur terendap, baru air kapur di tuang kedalam wadah yang sudah di siapkan, agar sisa kapur yang ada di dalam tidak terikut pada air penelitian. Selama sampling, dilakukan pergantian air sebanyak $50 \%$ dan penembahan kapur sesuai dengan perlakuan pada setiap ember pemeliharaan. Hal ini bertujuan untuk mempertahankan $\mathrm{pH}$ air sesuai dengan $\mathrm{pH}$ sebelum pergantian air.

\section{Pemeliharaan ikan}

Kegiatan pengamatan pertumbuhan (pemeliharaan) ikan dilakukan untuk mengevaluasi efektivitas pemberian kapur dalam meningkatkan $\mathrm{pH}$ air pada kelangsungan hidup dan pertumbuhan benih ikan gabus.Setelah proses aklimatisasi dan penembahan kapur selesai, benih ikan gabus ditimbang, dan diukur panjang benih ikan gabus.. Selanjutnya, benih ikan gabus dipelihara selama 60 hari dimana setiap 14 hari akan dilakukan sampling dengan menimbang berat dan mengukur panjang ikan sebagai sampel diambil 5 ekor ikan disetiap perlakuan. Selama pemeliharaan benih ikan gabus diberikan pakan buatan komersial sebanyak 5\% dari total berat populasi. Frekuensi pemberian pakan selama pemeliharaan sebanyak dua kali sehari pada pagi hari pukul 08.00 WIB dan sore hari pukul 17.00 WIB. Pada akhir penelitian, benih ikan gabus ditimbang, diukur panjang benih ikan gabus, dan pengambilan sampel ikan gabus pada setiap perlakuan. Pengukuran fisika dan kimia air meliputi: $\mathrm{pH}$ diukur setiap sehari, suhu diukur setiap haridan DO diukur setiap 14 hari sekali. 


\section{Parameter yang diamati}

\section{Kelangsungan Hidup} sebagai berikut:

Tingkat kelangsungan hidup ikan selama pemeliharaan dihitung menggunakan rumus Effendie, (1997),

$$
\mathrm{SR}=\frac{\mathrm{Nt}}{\mathrm{No}} \times 100 \%
$$

Keterangan:

SR = Survival Rate atau Kelangsungan hidup ikan (\%)

$\mathrm{Nt}=$ Jumlah ikan akhir pemeliharaan

No $=$ Jumlah ikan pada awal pemeliharaan

\section{Pertumbuhan}

Pertumbuhan diukur dengan mengambil sampel ikan $10 \%$ dari padat tebar selama pemeliharaan.

- Pertumbuhan berat

Menurut rumus Effendie (1997) sebagai berikut :

$$
W=W t-W o
$$

Keterangan :

$\mathrm{W}=$ Pertumbuhan berat mutlak ikan yang dipelihara (gram)

$\mathrm{Wt}=$ Berat ikan pada akhir pemeliharaan (gram

Wo $=$ Berat ikan pada awal pemeliharaan (gram)

- Pertumbuhan Panjang

Menurut rumus Effendie (1997) sebagai berikut :

Keterangan :

$$
\mathrm{L}=\mathrm{Lt}-\mathrm{Lo}
$$

$\mathrm{L}=$ Pertumbuhan Panjang mutlak ikan yang dipelihara $(\mathrm{cm})$

$\mathrm{Lt}=$ Panjang ikan pada akhir pemeliharaan $(\mathrm{cm})$

Lo $=$ Panjang ikan pada awal pemeliharaan $(\mathrm{cm})$

\section{Laju Pertumbuhan Spesifik (specific growth rate, SGR)}

Pertumbuhan berat sebagai data pertumbuhan ikan yang diukur pada tiap 14 hari sekali untuk mengetahui pengaruh dari pemeberian pakan komersial pada setiap perlakukan. Laju pertumbuhan spesifik ikan dihitung dengan menggunakan rumus Zonneveld et al., (1991) :

$$
\mathrm{SGR}=\frac{\ln W t-\ln W_{0}}{t} \times 1005
$$

Keterangan :

SGR = Specific Growth Rate (Laju pertumbuhan spesifik, \%/hari)

$\mathrm{Wt} \quad=$ Final Body Weight (Rata-rata bobot ikan uji akhir penelitian, g)

Wo = Initial Body Weight (Rata-rata bobot ikan uji awal penelitian, g)

$\mathrm{t} \quad=$ Time (Lama pemeliharaan, hari)

\section{Rasio Konversi Pakan}

Perhitungan rasio konversi pakan atau Feed Conversiion ratio (FCR) berdasarkan Effendie (1997), yaitu sebagai berikut:

Keterangan :

$$
\mathrm{FCR}=\mathrm{F} /((\mathrm{Wt}+\mathrm{d})-\mathrm{Wo})
$$

FCR $=$ Feed Convertion Ratio.

Wo $=$ Bobot hewan uji pada awal penelitian .

$\mathrm{Wt}=$ Bobot hewan uji pada akhir penelitian .

$\mathrm{D}=$ Jumlah ikan yang mati

$\mathrm{F}=$ Jumlah pakan yang dikonsumsi.

\section{Kualitas Air}

Parameter kualitas air yang diukur yaitu $\mathrm{pH}$, suhu, oksigen terlarut. Pengukuran fisika dan kimia air diantaranya $\mathrm{pH}$ diukur setiap hari dalam pemeliharaan, DO diukur persampling (14 hari), dan suhu di ukur setiap hari selama pemeliharaan. 


\section{Analisis Data}

Dalam penelitian ini rancangan yang akan digunakan adalah Rancangan Acak Lengkap (RAL) dengan empat perlakuan (A,B,C,D) dan tiga ulangan $(1,2,3)$

Data yang diperoleh dianalisis dengan sidik ragam (ANOVA) yang diolah menggunakan software SPSS. Jika perlakuan memberikan pengaruh sangat nyata, maka pengujian dilanjutkan dengan uji beda Duncan pada taraf $5 \%$ untuk mengetahui perbedaan antar perlakuan.

\section{Kelangsungan Hidup}

\section{HASIL DAN PEMBAHASAN}

Kelangsungan hidup pada perlakuan penambahan kapur dan kontrol memiliki nilai yang berbeda, pada penambahan kapur kelangsungan hidup rata-rata bernilai 60\% sedangkan pada kontrol memiliki nilai rata-rata $30 \%$. Hasil analisis statistik dengan menggunakan ANOVA untuk mengetahui pengaruh pemberian kapur pada media air gambut terhadap kelangsungan hidup ikan gabus (Channa striata) diperoleh nilai Sig. $(0,14)>0,05$ dimana hal ini berarti bahwa pemberian kapur tidak berpengaruh nyata terhadap kelangsungan hidup ikan gabus (Channa striata). Kelangsungan hidup terbaik terdapat pada perlakuan D penambahan kapur (250g) dengan nilai 57,73\% dan tingkat kelangsungan hidup terendah terdapat pada A (kontrol) dengan nilai 26,63\%. Untuk lebih jelasnya dapat dilihat pada Gambar 1.

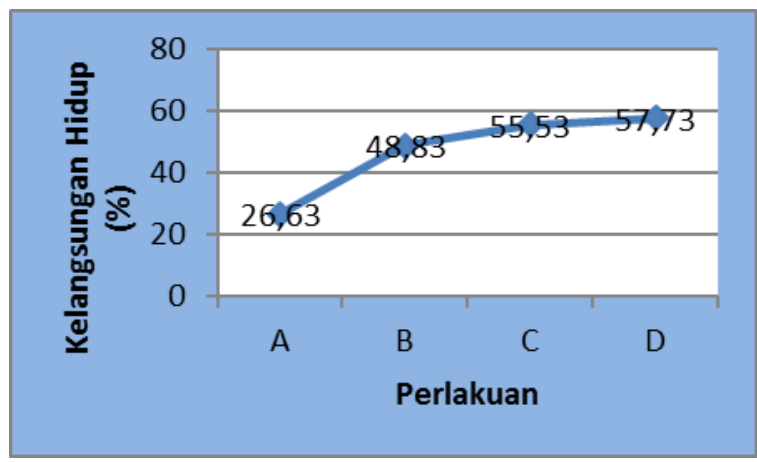

Gambar 1. Grafik Kelangsungan Hidup Benih Ikan Gabus

Berdasarkan Gambar 1, dapat diketahui bahwa penambahan kapur pada air gambut tidak memberikan pengaruh nyata terhadap kelangsungan hidup benih ikan gabus. Data hasil penelitian menunjukkan bahwa persentase kelangsungan hidup benih ikan gabus tertinggi terdapat pada perlakuan D dengan dosis 250 gram dengan nilai 57,7 $\%$ dan yang terendah terdapat pada perlakuan A (kontrol) dengan nilai 28,8\%.

Tingkat kelangsungan hidup (Survival Rate/SR) terendah terdapat pada perlakuan A yaitu kontrol terjadi karena kematian ikan pada perlakuan A (kontrol) ulangan kedua mengalami stress saat dilakukan pengukuran (sampling) pertama, ikan terkena penyakit dan $\mathrm{pH}$ pada kontrol sangat rendah sehingga banyak yang mati. Berdasarkan hasil pengamatan benih ikan gabus selama pemeliharaan, kematian benih ikan gabus diduga akibat infeksi bakteri dan jamur. Kelainan klinis seperti timbul bentuk kapas putih pada tubuh benih ikan gabus, mata menonjol, adanya bercak merah pada salah satu sirip dada, seluruh tubuh melepuh, dan luka-luka. Adanya penyakit pada benih ikan gabus, terjadi pada saat dua minggu pemeliharan benih ikan gabus. Kondisi tersebut juga terjadi pada penelitian Sopian (2013), bahwa rendahnya nilai kelangsungan hidup benih ikan gabus disebabkan serangan penyakit dan sifat kanibalisme ikan gabus. Menurut Angga dan Safrudin (1982) dalam Mutaqin (2006) bahwa stres merupakan gangguan mekanisme homeostatik, sehingga memudahkan terjadinya suatu penyakit. Kualitas air mempunyai peranan penting sebagai pendukung kehidupan dan pertumbuhan benih ikan gabus. Sedangkan SR tertinggi terdapat pada perlakuan D dengan nilai 57,73\% hal ini disebabkan karena kualitas air yang mendukung dan masih dalam batas normal. Menurut Kordi (2011), ikan gabus merupakan ikan yang mampu hidup pada perairan dengan kandungan oksigen rendah hingga $2 \mathrm{mg} / \mathrm{L}$. Kelangsungan hidup berhubungan dengan ketahanan tubuh atau sistem imun, ketersediaan pakan dan kesesuaian lingkungan hidup. Lingkungan hidup yaitu media pemeliharaan air masih pada batas kisaran normal untuk pemeliharaan benih ikan gabus. Data mortalitas menunjukkan bahwa kematian ikan terjadi pada awal pemeliharaan dimana ikan masih beradaptasi terhadap lingkungan sedangkan kematian ikan lainnya terjadi sehari setelah dilakukan sampling pertumbuhan berat dan panjang. Kematian ikan ini diperkirakan akibat stress pada ikan setelah dilakukan sampling.

Dari hasil analisis sidik ragam menggunakan ANOVA diketahui bahwa pemberian kapur tidak berpengaruh nyata terhadap kelangsungan hidup benih ikan gabus hal ini terjadi karena jumlah mortalitas yang terlalu berbeda antara perlakuan pemberian kapur dan kontrol. 


\section{Pertumbuhan Berat}

Pertumbuhan berat selama penelitian disajikan pada Gambar 2 berikut :

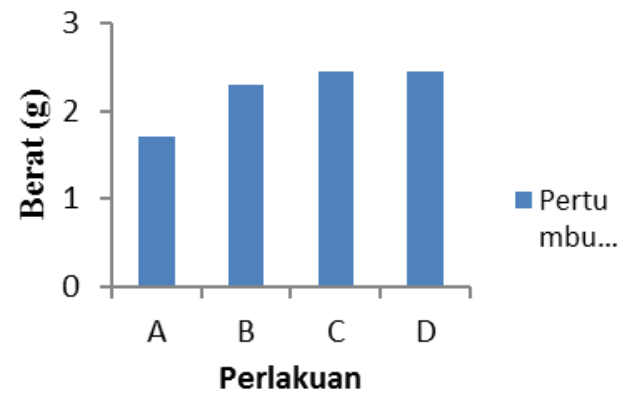

Gambar 2. Grafik Pertumbuhan Berat

Berdasarkan analisa sidik ragam bahwa pemberian kapur tidak berpengaruh nyata terhadap pertumbuhan berat benih ikan gabus. Grafik hasil analisa regresi hubungan antara waktu pemeliharaan dengan pertumbuhan berat ikan disajikan pada Gambar 2. Pertumbuhan berat terbaik didapat pada perlakuan C dengan dosis 200 gram dengan nilai 3,16 gram dan nilai terendah terdapat pada perlakuan A dengan nilai 1,71 gram. Hal ini diduga karena pada perlakuan $\mathrm{C}$ nafsu makan ikan lebih tinggi sehingga pertumbuhan ikan akan lebih cepat dan baik dan lingkungan yang baik akan memberikan kondisi yang baik bagi ikan untuk melakukan aktivitas sehingga dapat mendukung pertumbuhan ikan. Pertumbuhan dipengaruhi oleh beberapa faktor yaitu faktor dari dalam dan faktor dari luar. Faktor dari luar meliputi lingkungan, terutama sifat fisika, kimia dan biologi perairan Prihadi (2007).. Berbeda dengan perlakuan A, dan B yang memberikan hasil yang cukup rendah dan juga karena faktor lingkungan yang menyebabkan ikan kehilangan nafsu makan akibatnya cenderung lambat untuk tumbuh dan juga pada $\mathrm{C}$ diduga ikan lebih memanfaatkan energi dari makanan untuk mempertahankan hidup daripada pertumbuhan.

Dari data pengukuran biomasaa terlihat bahwa D cukup baik dibanding $\mathrm{C}$, diperoleh nilai yang cukup baik yaitu 3,13 gram dibandingkan D yaitu 3,16 gram. Hal ini berhubungan dengan kelangsungan hidup ikan gabus dimana pada D kelangsungan hidup cukup tinggi sehingga pada perlakuan D dapat dikatakan baik untuk pertumbuhan berat.

\section{Pertumbuhan Panjang}

Pertumbuhan panjang selama penelitian disajikan pada Gambar 3 berikut:

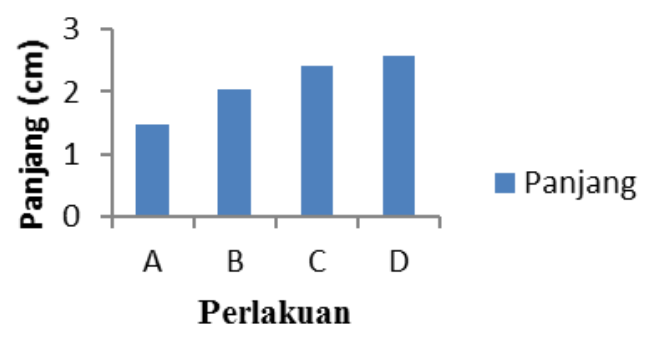

Gambar 3. Grafik Pertumbuhan Panjang

Analisis ragam menunjukkan bahwa penggunaan kapur pada air gambut tidak berpengaruh nyata terhadap pertumbuhan panjang benih ikan gabus. Meskipun secara ANOVA tidak berepengaruh nyata, namun pertumbuhan panjang tertinggi terdapat pada perlakuan D $250 \mathrm{~g}$ kapur dengan nilai $2,5 \mathrm{~cm}$, sedangkan pertumbuhan terendah terdapat pada perlakuan A kontrol dengan nilai $1,4 \mathrm{~cm}$. Prihadi (2007), menyatakan pertumbuhan panjang dipengaruhi oleh beberapa faktor dari dalam dan faktor luar, adapun faktor dari dalam meliputi sifat keturunan, ketahanan terhadap penyakit dan kemampuan dalam memanfaatkan makanan, sedangkan faktor dari luar meliputi sifat kimia dan biologi perairan. Faktor makanan dan suhu perairan merupakan faktor utama yang dapat mempengaruhi pertumbuhan benih ikan gabus.Pertumbuhan panjang ini juga berhubungan dengan asupan energi dari makanan terutamadigunakan untuk hidup (maintenance), jika ada kelebihan energi maka dapat digunakan untuk pertumbuhan panjang ikan. 


\section{Laju Pertumbuhan Spesifik (SGR)}

Hasil analisis statistik dengan menggunakan ANOVAuntuk mengetahui pengaruh pemberian kapur pada media air gambut terhadap laju pertumbuhan spesifik benih ikan gabus diperoleh nilai Sig. $(0,08)>0,05$ dimana hal ini berarti bahwa pemberian kapur tidak berpengaruh nyata terhadap laju pertumbuhan spesifik ikan gabus.

Laju pertumbuhan spesifik tertinggi dari penelitian ini terdapat pada perlakuan D penambahan kapur $250 \mathrm{~g}$ dengan nilai 2,92\% dan yang terendah terdapat pada perlakuan A (kontrol) dengan nilai 1,80\%. Untuk lebih jelasnya dapat dilihat pada Gambar 6.

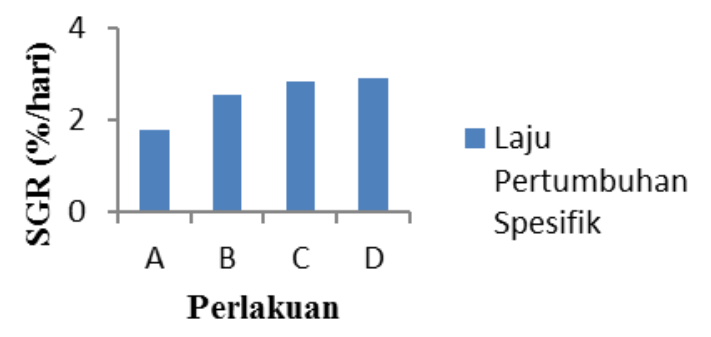

Gambar 4. Grafik Laju Pertumbuhan Spesifik

Laju pertumbuhan spesifik menunjukkan persentase kenaikan bobot ikan setiap hari selama penelitian (Rahmawati dan Samidjan, 2013). Laju pertumbuhan spesifik Selama 60 hari masa pemeliharaan benih ikan gabus tertinggi pada perlakuan D dengan dosis kapur 250 g dengan nilai 2,92\%/hari diikuti perlakuan C dengan dosis kapur $200 \mathrm{~g}$ dengan nilai 2,85\%/hari selanjutnya perlakuan B dengan dosis $150 \mathrm{~g}$ dengan nilai 2,54\%/hari dan terendah pada perlakuan A sebagai kontrol dengan nilai 1,80\%/hari. Pertumbuhan ini secara fisik diekspresikan dengan adanya perubahan jumlah atau ukuran sel penyusun jaringan tubuh pada periode waktu tertentu.

\section{Rasio Konversi Pakan}

Hasil yang diperoleh dalam penelitian ini menunjukkan Rasio konversi pakan benih ikan gabus memiliki perbedaan dalam setiap perlakuan. Rasio konversi pakan benih ikan gabus selama penelitian disajikan pada Gambar 5.

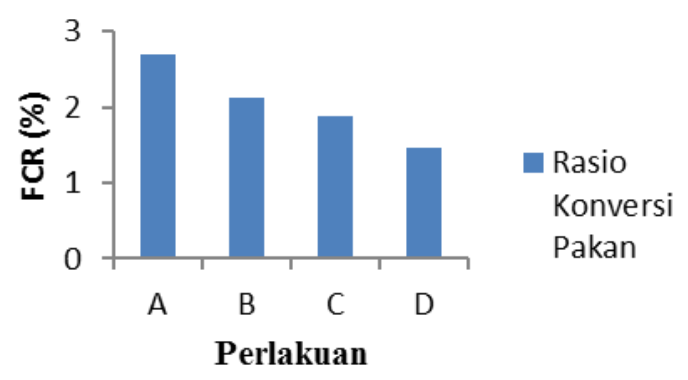

Gambar 5. Grafik Rasio Konversi Pakan

Hasil analisis statistik dengan menggunakan ANOVA untuk mengetahui pengaruh pemebrian kapur pada media air gambut terhadap rasio konversi pakan benih ikan gabus diperoleh nilai Sig. $(0,04)>0,05$ dimana hal ini menunjukkan bahwa pemberian kapur berpengaruh nyata terhadap rasio konversi pakan benih ikan gabus sehingga dapat dilanjutkan dengan uji lanjut Duncan yaitu dimana terhadap perbedaan nyata antara perlakuan. Berdasarkan hasil uji lanjut Duncan rasio konversi pakan pakan benih ikan gabus (Channa striata) menunjukkan perlakuan A,B,C berpengaruh nyata terhadap Perlakuan D, sedangkan Perlakuan B, C tidak berpengaruh nyata terhadap Perlakuan A. Perlakaun C,A juga tidak berpengaruh nyata pada Perlakuan B dan Perlakuan C juga tidak berpengaruh nyata pada Perlakuan A.

Rasio konversi pakan merupakan perbandingan antara jumlah pakan yang diberikan dengan berat tubuh ikan yang dihasilkan. Semakin kecil nilai konversi pakan menunjukkan tingkat efesiensi pemanfaatan pakan lebih baik oleh benih ikan gabus, dan lebih efisien digunakan untuk pertumbuhan, sebaiknya jika nilai konversi pakan kurang baik. Sesuai dengan pemikiran (Arief et al., (2014) bahwa tingkat efisien penggunaan pakan yang terbaik akan dicapai pada nilai perhitungan konversi pakan terendah. Aktivitas pengambilan pakan ikan berkaitan erat dengan nafsu makan, dan nafsu makan akan menetukan jumlah pakan yang dikonsumsi (Feed intake).

Dari hasil penelitian nilai rasio konversi pakan tertinggi terdapat pada Perlakuan kontrol dengan nilai 2,69 dan nilai rasio konversi pakan terendah terdapat pada Perlakuan D dengan dosis kapur 250 gram dengan nilai 1,47. 
Nilai konversi pakan yang rendah pada perlakuan pemberian kapur untuk benih ikan gabus diduga akibat dari pemanfaatan pakan yang baik.

Nilai konversi pakan yang semakin kecil menunjukkan tingkat effesien makanan tersebut baik. Nilai konversi pakan juga tidak lepas dengan nilai protein rasio untuk memenuhi kebutuhan protein pakan benih ikan gabus merupakan ikan karnivora (kanibalisme).

\section{Kualitas Air}

Pengukuran parameter kualitas air terdiri atas suhu, derajat keasaman, oksigen terlarut data hasil pengukuran kualitas air tersaji pada Tabel 1.

Tabel 1. Data Hasil Pengukuran Kualitas Air Selama Penelitian

\begin{tabular}{cccc}
\hline Perlakuan & $\mathrm{pH}$ & Suhu & DO \\
\hline A1 & 4,15 & 26,3 & 1,53 \\
A2 & 4,15 & 26,3 & 2,92 \\
A3 & 4,37 & 26,3 & 1,45 \\
B1 & 6,13 & 26,3 & 1,89 \\
B2 & 6,47 & 26,3 & 1,99 \\
B3 & 6,81 & 26,3 & 2,15 \\
C1 & 6,19 & 26,3 & 1,51 \\
C2 & 6,59 & 26,3 & 1,40 \\
C3 & 6,87 & 26,3 & 1,34 \\
D1 & 6,57 & 26,3 & 1,55 \\
D2 & 6,94 & 26,3 & 1,56 \\
D3 & 6,97 & 26,3 & 1,71 \\
\hline
\end{tabular}

Sumber. Data Primer, 2020

Berdasarkan tabel diatas, kualitas air pada saat pemeliharaan menunjukkan kisaran angka yang masih mampu untuk mendukung kelangsungan hidup dan pertumbuhan benih ikan gabus (Channa striata).Kualitas air mempunyai peranan penting sebagai pendukung kehidupan pertumbuhan benih ikan gabus. Hasil pengukuran beberapa perubahan kualitas air pada penelitian ini meliputi : suhu, $\mathrm{pH}$, dan DO pada setiap perlakuan. Berdasarkan hasil pengukuran nilai variabel kualitas air menunjukkan kelayakan sebagai media budiidaya ikan gabus. Hasil pengukuran suhu selama penelitian $26-28^{\circ} \mathrm{C}$, pH berkisar 5-7, oksigen terlarut berkisar 0,70-2.15. Menurut Extrada et al. (2013) suhu optimun untuk ikan gabus berkisar $25-32^{\circ} \mathrm{C}$. Menurut BPBAT Mandiangin (2014) pH berkisar 4-7. KEPMEN$\mathrm{KP}$ (2015) menyatakan oksigen terlarut berkisar 0,5-7,4 mg/L.

Ikan gabus mempunyai kelebihan yaitu mampu mentolerir kondisi yang tidak menguntungkan seperti kadar oksigen yang rendah, $\mathrm{pH}$ rendah serta hidupnya tidak memerlukan air yang deras (Paray et al., 2013; Kusumaningrum et al., 2014). Ikan gabus memiliki sepasang rongga suprabranchial untuk bernapas lewat udara dan inilah alasan kenapa daya tahannya tangguh dan dapat hidup lama tanpa air, jika tetap menjaga kelembapan (Rahman dan Awal, 2016).

Kualiats air diduga berpengaruh terhadap nafsu makan ikan gabus untuk mengkonsumsi pakan yang diberikan. Menurut Subandiyono dan Hastuti (2016) faktor oksigen, suhu mempengaruhi tingkat stress dan menekan nafsu makan. Apabila ikan mengalami stress dan nafsu makan menurun akibat perubahan kualitas air maka pakan yang diberikan pun tidak diduga tidak mampu menarik data rangsangan ikan untuk menemukan dan mengkonsumsi pakan yang diberikan pada benih ikan gabus. Menurut pengukuran data kualitas air yang menunjukkan kelayakan media budidaya ikan gabus dan kemampuan yang dapat mentolerir berbagai parameter kualitas air, maka kondisi ikan dalam keadaan nyaman dan memiliki rangsangan nafsu untuk makan.

\section{Kesimpulan}

\section{KESIMPULAN DAN SARAN}

Berdasarkan penelitian dan hasil analisis data yang telah dilakukan diperoleh kesimpulan bahwa pemeliharaan benih ikan gabus selama 60 hari pada air gambut dengan pemberian kapur dengan dosis 250 gram mengasilkan kelangsungan hidup terbaik 57,7 gram dan pemberian kapur 200 gram mengasilkan pertumbuhan berta terbaik 3,16 g, pemberian kapur $250 \mathrm{~g}$ menghasilkan pertumbuhan panjang terbaik $2,5 \mathrm{~cm}$, pemberian kapur $250 \mathrm{~g}$ menghasilkan laju pertumbuhan spesifik terbaik 2,92\%/hari, dan pemberian kapur $250 \mathrm{~g}$ menghasilkan rasio konversi pakan terbaik $1,47 \%$ merupakan dosis terbaik.

\section{Saran}


Berdasarkan penelitian yang telah dilakukan, perlu dilakukan penelitian mengenai aplikasi pemberian kapur melalui media air pada spesies ikan lainnya, dan juga dengan menggunakan dosis kapur 250 gram per-8 liter menggunakan air gambut, khususnya pada spesies-spesies ikan lokal Kalimantan Tengah.

\section{DAFTAR PUSTAKA}

Arief M., Nur F. dan Sri S. 2014. Pengaruh Pemberian Probiotik Berbeda Pada Pakan Komersial Terhadap Pertumbuhan dan Efisiensi Pakan Ikan Lele Sangkuriang (Clarias Sp.). Jurnal Ilmiah Perikanan dan Kelautan, $6(1): 1-5$ hal.

Ashari, Frengki. 2012. Variasi Ketebalan Lapisan dan Ukuran Butiran Media Penyaringan pada Biosand Filter untuk Pengolahan Air Gambut. Tugas Akhir Teknik Sipil Universitas Riau.

BPBAT Mandiangin. 2014. Naskah Akademik Ikan Gabus Haruan (Channa striatus Bloch 1793) Hasil Domestifikasi. Direktorat Jenderal Perikanan dan Budidaya, Mandiangin, $67 \mathrm{hlm}$

Effendie, M.I. 1997. Biologi Perikanan. Yayasan Pustaka Nusantara, Yogyakarta. 163 halaman.

Extrada, E., H.T. Ferdinand dan Yulisman. 2013. Kelangsungan Hidup dan Pertumbuhan Benih Ikan Gabus (Channa striata) pada Berbagai Tingkat Ketinggian Air Media Pemeliharaan. Jurnal Akuakultur Rawa Indonesia, 1(1):103114.

Gleni, H. W. dan G. Rudhy. 2013. Peningkatan Produktivitas Budidaya Ikan di Lahan gambut. Balai Penelitian dan Pengembangan Budidaya Air Tawar. Media Akuakultur Volume 8, [1].

Huwoyon, G.H., Sulhi, M., Gustiano, R., Mudjiutami, E., Wahyutomo, \& Prihadi, T.H. 2010. Keragaan pertumbuhan ikan nila best dan lokal di lahan gambut. Prosiding Seminar Nasional Perikanan Indonesia. 2-3 Desember 2010. Sekolah Tinggi Perikanan, Jakarta, hlm. 134-139.

Mutaqin, Z. 2006. Pola sebaran hama dan penyakit ikan yang disebabkan oleh penyakit dan bakteri pada beberapa provinsi di Indonesia. Skripsi. Institut Pertanian Bogar. Fakultas Kedokteran Hewan. Bogor. (Dipublikasikan).

Kordi, K. M. G. H. 2011. Panduan Lengkap Bisnis dan Budidaya Ikan Gabus. Lily Puslisher. Yogyakarta.

Kusumaningrum GA, Alamsjah MA, Masitah ED. 2014. Uji Kadar Albumin dan Pertumbuhan Ikan Gabus (Channa striata) Dengan Kadar Protein Komersial Yang Berbeda. Jurnal Ilmiah Perikanan dan Kelautan. 6(1): 25-29.

Prihadi, D. J. 2007. Pengaruh Jenis dan Waktu Pemberian Pakan Terhadap Tingkat Kelangsungan Hidup dan Pertumbuhan Kerapu Macan (Epinephelus fuscoguttatus) Dalam Keramba Jaring Apung di Balai Budidaya Laut Lampung. Fakulats Perikan dan Ilmu Kelautan Universitas Padjadjaran. Bandung. Jurnal Akuakultur Indonesia 493-953-1.

Zonneveld, N,. E. A. Huisman dan J. H. Boon. 1991. Prinsip-prinsip budidaya ikan. PT. Gramedia Pustaka Utama, Jakarta. 318 halaman 